\title{
Early effects of the COVID-19 outbreak on the African dairy industry: Cases of Burkina Faso, Kenya, Madagascar, and Senegal
}

Eric Vall ${ }^{1,16, *}$, John Mburu ${ }^{2}$, Asaah Ndambi $^{3}$, Cheikh Sall $^{4}$, Astou Diaw Camara ${ }^{4}$, Anna Sow ${ }^{5,16}$, Koki Ba ${ }^{4}$, Christian Corniaux ${ }^{1,16}$, Arona Diaw ${ }^{6}$, Djibril Seck ${ }^{7}$, Mathieu Vigne ${ }^{8,16}$, Sarah Audouin ${ }^{9,16,}$ Lovaniaina Jean Elisée Rakotomalala $^{10}$, Lynah Nirina Rakotonoely ${ }^{10}$, Flavio Dias Ferreira ${ }^{11}$, Erica Véromalalanirina ${ }^{11}$, Mahery Rajaonera ${ }^{12}$, Souleymane Ouédraogo ${ }^{13}$, Etienne Sodré ${ }^{13}$, Idrissa Tall $^{14}$, Madeleine Diallo Ilboudo ${ }^{15}$ and Guillaume Duteurtre ${ }^{1,16}$

${ }^{1}$ CIRAD, UMR SELMET, F-34398 Montpellier, France

2 Department of Agricultural Economics, University of Nairobi, Nairobi, Kenya

3 Wageningen University \& Research, Wageningen, The Netherlands

${ }^{4}$ ISRA, LNERV, Front de Terre, Hann Mariste, BP 2057, Dakar, Senegal

${ }^{5}$ CIRAD, UMR SELMET, Dakar, Senegal

${ }^{6}$ Laiterie du Berger, BP 24001, Ouakam, Dakar, Senegal

${ }^{7}$ Kirène, SIAGRO, BP 7020, Dakar, Senegal

8 CIRAD, UMR SELMET, Antsirabé 110, Madagascar

9 CIRAD, UMR INNOVATION, Antsirabé 110, Madagascar

${ }^{10}$ FIFAMANOR, BP 198, Antsirabé 110, Madagascar

11 SOCOLAIT, BP 206, Route Mandaniresaka, Antsirabe 110, Madagascar

12 SODIMILK, Saharoalahoha, Antsirabé 1, Madagascar

13 INERA, Station de Farako-Bâ, 01 BP 910, Bobo-Dioulasso 01, Burkina Faso

${ }^{14}$ Plateforme lait de Banfora, Banfora, Burkina Faso

15 Bonnet Vert, BP 179, Bobo-Dioulasso, Burkina Faso

${ }^{16}$ Univ Montpellier, CIRAD, INRAE, Institut Agro, Montpellier, France

\begin{abstract}
This paper provides an early assessment of the effects of the COVID-19 outbreak and of subsequent response measures on milk production, collection, processing, marketing and consumption in Africa. We focus on the period surrounding the first wave of the outbreak (from February to June 2020), during which the number of cases surged and many steps were taken to curb the epidemic. The paper is based on reports from four countries covered by the Africa-Milk Research Project: Burkina Faso, Kenya, Madagascar and Senegal. Data was collected primarily from nine dairy processors located in those countries. Major conclusions of the study are: (1) Dairy farmers were negatively affected by COVID-19 measures when the health crisis coincided with the peak of the milk production season, and when governments did not take steps to support milk production. (2) Small and informal milk collectors were also affected by traffic restrictions as they could not obtain traffic permits. (3) Milk powder importation remained unaffected during the outbreak. (4) Dairy processors (particularly small ones) faced many challenges restricting their operation. Travel restrictions led to temporary interruptions of milk supply, and because of employee protection and safety measures, processing costs increased. (5) Many small retailers were affected by bans on public transport and reduced their purchases of artisanal dairy products; meanwhile, spoilage of dairy products increased during long curfews coupled with poor storage conditions. Supermarkets were able to increase their market share during the pandemic thanks to their connections with industrial dairy processors and wholesalers. (6) A majority of consumers decreased their consumption of dairy products due to a decrease of purchasing power. In some cases, an increase in consumption occurred (due to Ramadan month and dry season high temperatures) and consumption shifted towards long-life dairy products. (7) Overall, the consequences of the health crisis affected more small and informal dairy supply chains than the larger ones, which are more formal, better organised and finally more resilient to face this kind of global crisis.
\end{abstract}

\footnotetext{
*Corresponding author: eric.vall@cirad.fr
} 
Keywords: Milk production / milk collection / milk processing / COVID-19 / Africa

Résumé - Premiers effets de la pandémie de COVID-19 sur l'industrie laitière africaine : exemples du Burkina Faso, du Kenya, de Madagascar et du Sénégal. Cet article présente une évaluation préliminaire des effets de l'épidémie de COVID-19 et des mesures sanitaires mises en place sur la production, la collecte, la transformation, la commercialisation et la consommation du lait en Afrique. L'étude s'est concentrée sur la période correspondant à la première vague de l'épidémie (de février à juin 2020), au cours de laquelle le nombre de cas a augmenté et de nombreuses mesures ont été prises pour enrayer l'épidémie. L'article est basé sur des informations en provenance de quatre pays couverts par le projet de recherche Africa-Milk: le Burkina Faso, le Kenya, Madagascar et le Sénégal. Les données ont été collectées principalement auprès de neuf laiteries situées dans ces pays. Les principaux résultats sont les suivants. (1) Les producteurs de lait ont été gravement touchés par les mesures contre la COVID-19 lorsque la crise sanitaire a coïncidé avec le pic de la saison de production laitière et lorsque les gouvernements n'ont pas pris de mesures pour soutenir la production laitière. (2) Les petits collecteurs de lait informels ont été gravement touchés par les restrictions de déplacement car ils ne pouvaient pas obtenir de permis de circulation. (3) Aucun problème important n'a été signalé dans l'importation de lait en poudre pendant l'épidémie. (4) Les laiteries, en particulier les plus petites, ont dû faire face à de nombreux défis pour continuer à fonctionner pendant la crise sanitaire, en raison des contraintes de déplacement entraînant des interruptions temporaires de l'approvisionnement en lait, et en raison des mesures de protection et de sécurité de leurs employés qui ont augmenté les coûts de transformation. (5) De nombreux petits détaillants ont été touchés par l'interdiction des transports publics et ont réduit leurs achats de produits laitiers artisanaux; leurs pertes de produits laitiers ont augmenté pendant les longs couvre-feux combinés à de mauvaises conditions de stockage. Les supermarchés ont pu augmenter leur part de marché pendant la pandémie en raison de leurs liens avec les circuits industriels et les grossistes. (6) Une majorité de consommateurs ont diminué leur consommation de produits laitiers en raison d'une perte de pouvoir d'achat. Dans certains cas, une augmentation de la consommation s'est produite (en raison du Ramadan et de la canicule) et la consommation s'est déplacée vers les produits laitiers de longue conservation. (7) Dans 1'ensemble, les conséquences de la crise sanitaire ont plus durement touché les petites chaînes d'approvisionnement laitières informelles que les grandes chaînes d'approvisionnement laitières, mieux organisées et plus résilientes face à une telle crise.

Mots clés : Production du lait / collecte du lait / transformation du lait / COVID-19 / Afrique

\section{Introduction}

The milk industry is an important component of the agrifood economy in Africa. Over the last 50 years, the total consumption of milk products in Africa rose from 8.1 to 44.1 million tonnes of liquid milk equivalent (FAO, 2020). This growth is particularly pronounced in African cities where dietary habits are rapidly changing. Milk also represents an important part of small farmers' livelihoods, in particular in pastoral and agro-pastoral regions (Richard et al., 2019).

This sector, however, has been reported to suffer heavily since the first COVID-19 case was reported in Africa on the 14th of February, 2020. The continent recorded 201157 confirmed cases by the 9 th of June, 2020, including 5486 deaths. All countries on the continent were affected (WHO, 2020). Three months later, those figures had jumped to 1314148 confirmed COVID-19 cases and 31706 deaths. In October 2020, the World Health Organisation (WHO) reported that the COVID-19 outbreak might have passed its peak in Africa, but warned governments not to be complacent as countries relaxed their restrictions.

The effects of the COVID-19 outbreak and of related measures taken from February to June 2020 to curb the pandemic occurred during different seasons in each country, and therefore impacted the milk sector differently. In most countries, administrative measures were taken to curb the spread of the pandemic. Those steps included closing borders, imposing travel bans, dusk to dawn curfews, prohibiting mass gatherings, shutting down schools, and closing markets. However, in order to ensure food security for urban and rural populations, transportation of agricultural products was allowed at least during the day. Food production, processing, distribution and marketing have been preserved because they are considered as essential health care services. But despite the fact that transportation of agricultural products was allowed, restrictive measures taken during this state of emergency seriously affected all stakeholders in the milk value chain.

This paper is based on reports from four countries covered by the Africa-Milk Research Project (https://www.africa-milk. org/): Burkina Faso, Kenya, Madagascar, and Senegal. Those countries feature different agro-climatic conditions, from lowaltitude savannah regions (Senegal, Burkina Faso) to high and medium altitude tropical areas (Madagascar, Kenya), and a large diversity of dairy sectors (Tab. 1). In the study countries, the situation of dairy supply chains before the COVID-19 crisis was described by many authors in Kenya (Makoni et al., 2013; Kiambia et al., 2020), Senegal (Corniaux et al., 2014; Seck et al., 2016; Corniaux and Duteurtre, 2018), Burkina Faso (Corniaux et al., 2014; Corniaux and Duteurtre, 2018; GRET, 2019) and Madagascar (Penot et al., 2016; Droy and Rasolofo, 2018).

In Senegal and Burkina Faso, the outbreak emerged in March 2020, at the end of the dry season, a period of low production of local milk in agro-pastoral systems and very high 
Table 1. Schematic view of the domestic dairy sectors in the four countries studied as part of the Africa-Milk research project (source: FAOSTAT, years 2012 to 2017 depending on items).

Tableau 1. Données générales sur le secteur laitier dans les quatre pays étudiés participant au projet Africa-Milk (source: FAOSTAT, années 2012 à 2017 selon les indicateurs).

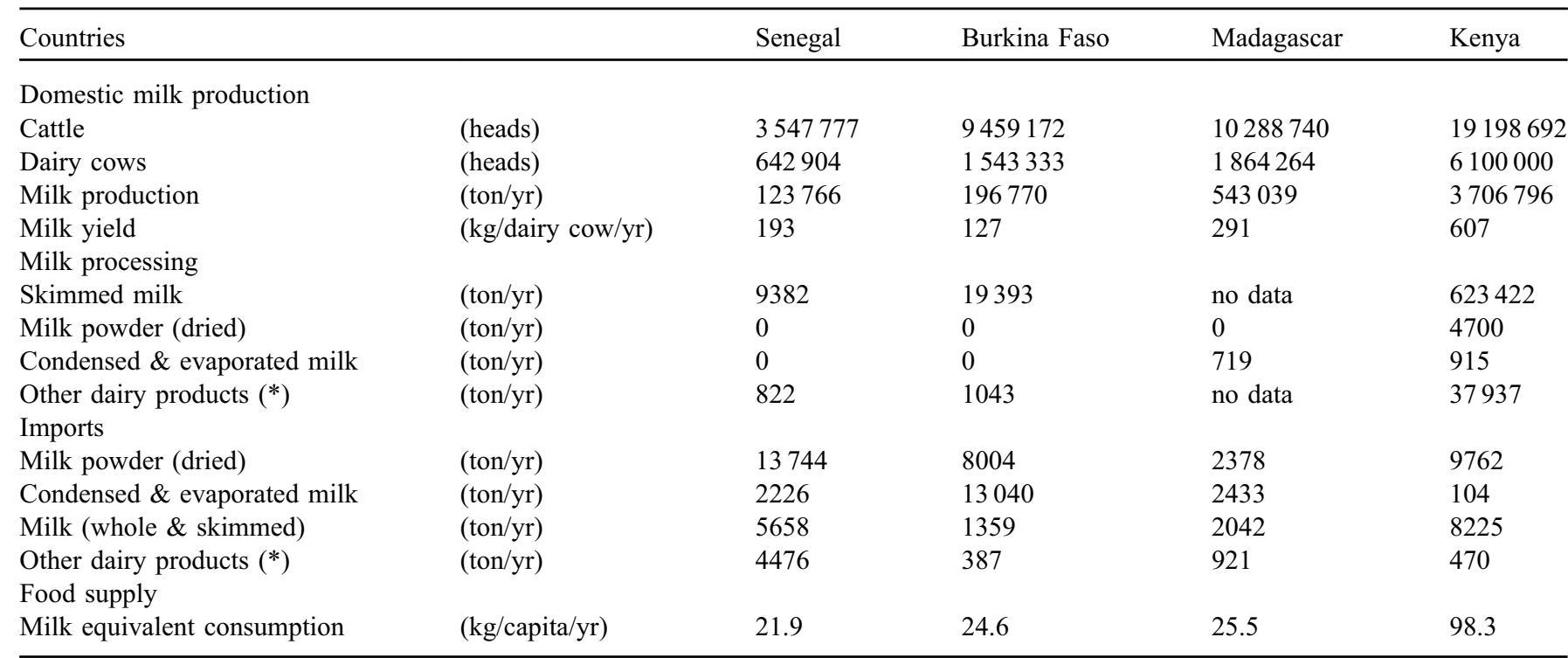

$\left(^{*}\right)$ cheese, butter, cream, yoghurts, etc.

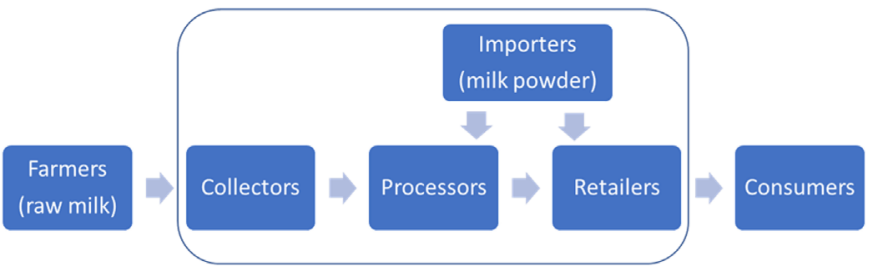

Fig. 1. Schematic view of dairy supply chains studied in this paper. Fig. 1. Schéma des filières laitières étudiées dans cet article.

consumers' demand due to the month of Ramadan (23 April23 May, 2020). In Kenya, it was also the end of the dry season, but with production systems being less dependent on rainfall due to more intensive production techniques. In Madagascar, the outbreak came during the rainy season, at the peak of production, when milk collection systems were most vulnerable to restriction measures.

In those four countries, dairy industry players faced major challenges as a result of quarantines, curfews, restrictions on use of public transport for dairy product distribution, check points, reduced opening hours for shops, and border closures.

The main objective of this paper is to study the effects of the crisis due to COVID-19 on the milk sector in four countries of sub-Saharan Africa, as a whole and for each of the link within the national dairy supply chain.

\section{Methodology}

Our study explores the initial impact of the measures put in place in response to COVID-19 on dairy supply chains. The dairy supply chain (Fig. 1), covers each actors of flows starting from the raw milk production at farm level, going to milk processing and to the consumers, including intermediaries in between (raw milk collectors and processed milk retailers).

Our paper builds on information gathered from nine dairy supply chains involved in the Africa-Milk Project, as well as some other dairy supply chains operating in the four selected countries. Each supply chain is centred around a dairy processor. The nine dairy processors involved in the study reflect a wide range of situations, from small-size to industrialsize operations (Tab. 2 and Fig. 2).

We also used some data published in newspapers or by NGOs and professional organisations.

Some milk value chains are based on mini-dairyprocessors with relatively poorly organised collection and distribution systems (Bonnet Vert, Plateforme Lait de Banfora, Sodimilk), others are based on intermediate or industrial dairy processors equipped with more organised collection and distribution systems (Socolait, Laiterie du Berger, Kirène, Happy Cow, Mukuruweini Wakulima ltd., NkCC).

In this paper we present the impact of the steps taken to curb the COVID-19 outbreak starting with dairy farmers, then following the dairy supply chain all the way to consumers. In each section we describe the stakeholders' situation during the health crisis, country by country, and in the final section we offer a cross-cutting analysis of the consequences of the crisis at each stage of the dairy supply chain.

\section{Results}

\subsection{Increased milk volumes and falling farm-gate prices for most countries}

In Kenya, dairy animals' productivity was not negatively affected by the crisis due to COVID-19. Milk production has 
Table 2. Schematic view of Africa-Milk's nine dairy processor partners (source: project data).

Tableau 2. Données générales sur les neuf laiteries partenaires du projet Africa-Milk (données du projet).

\begin{tabular}{llll}
\hline Type of dairy processor & Name (country) & L/day & Producers \\
\hline \multirow{3}{*}{ Small-size } & Bonnet Vert (BF) & 300 & 30 \\
& Plateforme Lait de Banfora (BF) & 800 & 100 \\
& Sodimilk (MD) & $1000-1500$ & 150 \\
& Kirène (SN) & $1500(\mathrm{~N})-300(\mathrm{~F})$ & $4(\mathrm{~N})-100(\mathrm{~F})$ \\
Medium-size & Laiterie du Berger (SN) & 4000 & 7000 \\
& Mukurweini Wakulima Dairy Ltd. (KE) & 9000 & 7400 \\
& Happy Cow Ltd. (KE) & 11000 & 2000 \\
Industrial-size & Socolait (MD) & 350000 & 1000000 \\
\hline
\end{tabular}

BF: Burkina Faso; KN: Kenya; MD: Madagascar; SN: Senegal; N: Niayes area; F: Fatick area.

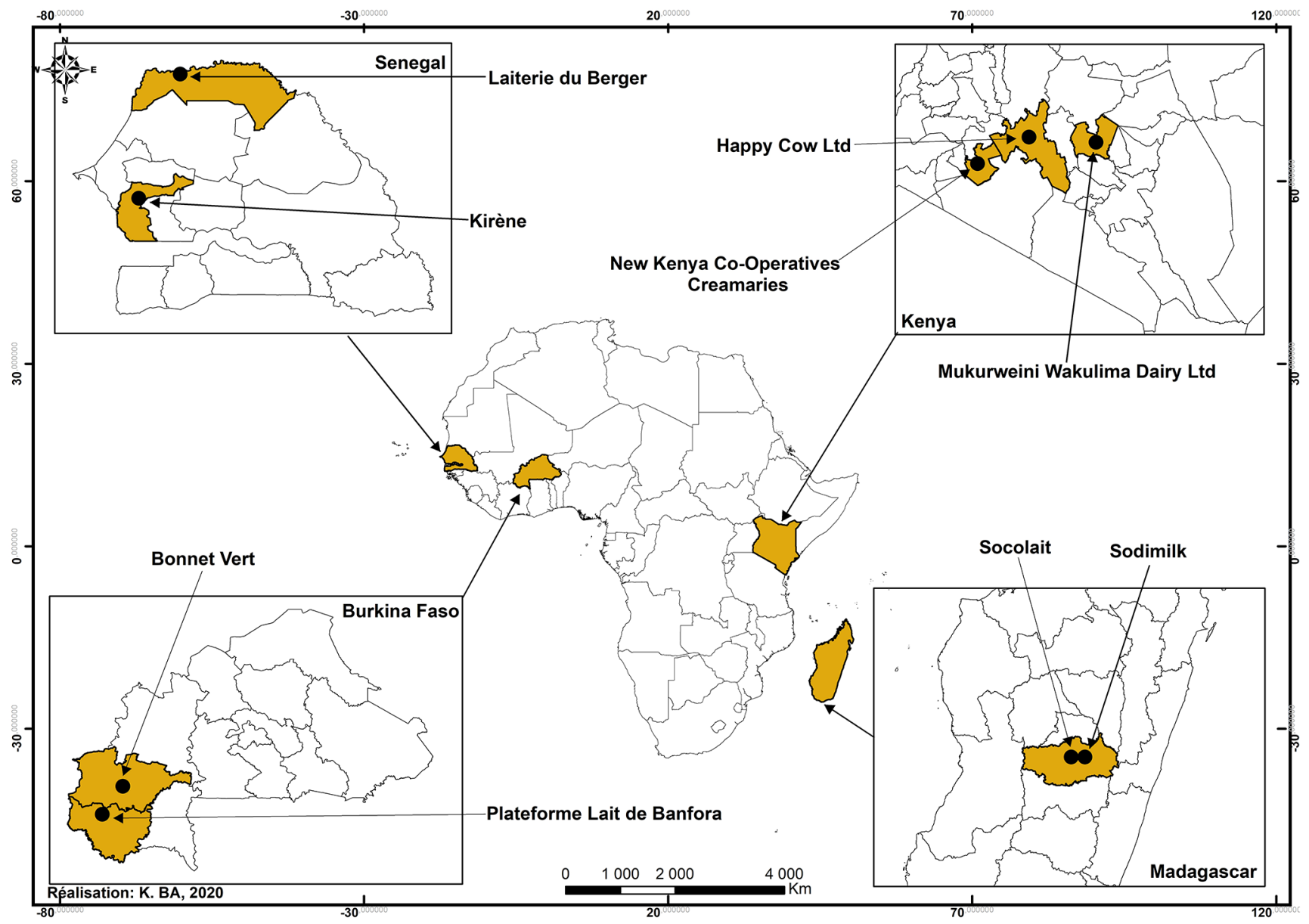

Fig. 2. Localization of the study sites and dairy processing partners of the Africa-Milk Project in each country.

Fig. 2. Localisation des sites d'étude et des laiteries partenaires du projet Africa-Milk dans chaque pays.

continued to increase since November 2019. In particular, COVID-19 infection rates were low in milkshed areas and agricultural activities did not changed much. Thus, with continued favourable weather conditions since November 2019, production costs per animal went down due to the availability of more fodder. Reduced availability of commercial feeds due to curtailed movement to Nairobi also encouraged farmers to make greater use of locally available fodder which is abundant in all milksheds during this period of the year. Since home-grown feeds are cheaper than commercial ones, this momentum led to a further drop in production costs, while also reducing the income of commercial feed suppliers. In addition, the Kenyan government took swift action to support the farm-gate price of milk in order to support dairy 
farmers. From the start of the COVID-19 outbreak, the Kenyan government had instructed its own processor (the NKCC) to buy milk from farmers at KES $33(0.28 €)$ per litre. This order forced collectively-owned and private processors to raise their farm-gate prices. For example, according to the Daily Nation Newspaper (April 2020), "Brookside Dairy, which controls $40 \%$ of the country's raw milk market, adjusted farm-gate prices upwards, with an incentive of an extra shilling per kilogramme of raw milk to cushion farmers from the effects of the COVID-19 disease". The order remained in force during the COVID-19 period and all the processors bought milk at prices near or above the government set price. Since this price is well above the milk production cost per litre (which, depending on feeding regimes, ranges between KES 22-27 per litre $-\sim 0.17$ to $0.21 €$ ), farmers' prosperity continued to increase despite the increased supply. Due to a drop in supply later in the year, farm gate milk prices remained high while consumer prices rose in September 2020 (Andae, 2020).

In Senegal, dairy farmers established in the milk collection area of Laiterie du Berger, were not badly affected by the lockdown, thanks to Laiterie du Berger's effective collection network and the provision of traffic permits for its collectors. Dairy farmers supplying Kirène were affected by mobility restrictions in various ways. In March, the Kirène collection centre in Fatick had to suspend milk collection for several weeks, for administrative reasons linked to COVID-19, whereas, paradoxically record levels of milk production were noticed. as a matter of fact, no official permits for transportation to the Kirène factory located near Dakar had been provided. Fatick milk producers, mostly small producers, were therefore badly affected by this measure. They ended up with unsold milk. On the other hand, these traffic restrictions led large dairy farmers established in Kirène second collection area, located in the Niayes region near the factory, to redirect all their production to the factory and to abandon the Dakar market. Indeed, before COVID-19, dairy farms favoured direct sales on the more profitable Dakar market. With traffic restrictions, this market has been suspended. Then, the dairy production of these farms was redirected to Kirène, located in the same area and therefore not constrained by mobility restrictions.

In Burkina Faso, some dairy farmers reported that COVID19 had no direct impact on cow feeding strategies and consequently on cow productivity. Stocks of fodder and feed were already high enough at this time, and milk production was on track. However, in the Bobo-Dioulasso milkshed, during the first month of travel restriction measures taken by the government, dairy farmers could not sell their milk because collectors could no longer get through checkpoints in order to deliver milk to dairy processors in town. In Banfora, farmers accustomed to delivering milk during the dry season also had difficulties because dairies were no longer able to sell all their products. As a result, they had to reduce the volumes of milk collected and processed on a daily basis. A dairy farmer located in the peri-urban area of Banfora reported that, during the first two months of the pandemic, Plateforme Lait de Banfora could only purchase 8 to 10 litres of the 20 to 25 litres of milk produced (i.e. $40 \%$ ). The rest was self-consumed by the farmer's family and given to vulnerable people, in particular displaced populations fleeing from terrorism in the north of the country. This significantly reduced farmers' incomes and thus their ability to cover fixed costs such as herdsmen's wages. This problem was mitigated by reducing the number of milking cows kept on the farm. Some of them were returned to the main herd kept by the herdsmen, who could then benefit from their milk as part of their salary.

In Madagascar, the period coincided with cows' peak lactation season. At the beginning of the outbreak, the Midi Madagaskari newspaper reported on the 31th of March, 2020, that "processing cooperatives have reduced their purchases from farmers from 1000 litres to 600 litres a day, which represents a drop of $40 \%$ ", and as a consequence, milk farmgate prices had fallen from 1600 to 1000 ariary per litre $(\sim 0.40$ to $0.25 €$ ). This was due to the decline in urban demand at the beginning of the crisis which forced many small-scale milk processors to shut down. Indeed, in the same newspaper, a dairy industry operator in the Vakinankaratra region reported: "In addition to transportation problems, we can only sell in the morning until noon (due to curfew). As a result, we only sell 300 litres a day instead of 700 litres before lockdown". Dairy farmers had large quantities of unsold milk, especially afternoon milk, and therefore had to sell it door-to-door or by the roadside. The dairy industry had already experienced several crises in the years 2001-2009 (Penot et al., 2016), from which it recovered in recent years. But there is still a risk of weariness amongst small-scale dairy farmers about remaining involved in the milk business. It is likely that, in the longer term, small-scale dairy farmers will be tempted to give up the dairy business and destock their dairy herd, leading to a reduction in milk production. This situation could potentially affect local processors in the medium term, and in particular large operators such as Socolait.

\subsection{Disruptions in milk collection and dairy processor supply}

In Kenya, milk collection channels were not heavily affected by the pandemic and experienced an oversupply of milk. The flow of the commodity was uninterrupted since it had been classified as an essential service. However, according to the Daily Nation Newspaper (2 June, 2020), farmers who were selling their milk through hawkers in the informal market were adversely affected and their milk sales decreased.

In Senegal, Laiterie du Berger reported on the 22nd of April: "We reached our targets in terms of turnover, and local milk sourcing is going well too: 100 tonnes in March 2020!" (according to Laiterie du Bergerhead of milk collection). For Kirène, the situation was not as straightforward. The head of milk collection at Kirène reported that the large intensive dairy farms established in the Niayes region (which do not depend on natural pasture to produce milk during the dry season) were struggling to sell their products on the local market, and had turned to the Kirène factory to sell all their production. On the 14th of April, milk collection quantities doubled overnight, raising the monthly sourcing forecast from 50000 to 100000 litres. Kirène warned of a risk of exceeding the plant absorption capacity, and so decided to introduce delivery quotas to manage this flow. The situation was quite different in Fatick where milk collection had been suspended due to traffic bans. 
In Burkina Faso, the manager of Plateforme Lait de Banfora expressed real concern in April about the possible consequences of the current situation, saying: "Here we are in quarantine. No one enters or leaves the town. Processors can no longer deliver products to customers. Collectors no longer have access to milk processing units" (2nd of April, 2020). Other managers of small dairies indeed witnessed a drop in collection during the health crisis. The manager of Bama's milk collection centre (Burkina Faso), who usually collects 100 litres of milk per day at this time of year, reported collecting 50 to 55 litres per day in mid-April. However, some dairy managers reported that official steps had been taken by the authorities to allow collectors to travel again. Bonnet Vert manager stated: "The regional department of the Ministry in charge of livestock production sent letters to the various police stations located at the city gates of Bobo-Dioulasso, along with details of the main collectors from the various milk collection centres. This enabled deliveries to resume after more than three weeks of interruption." A collector operating in the Banfora area admitted that it was still possible to deliver milk to Banfora, despite the low availability of milk during this dry season. According to him, low milk availability stemmed far more from the dry season than from COVID-19 restrictions. This collector usually collects 30 to 40 litres of milk per day in the dry season compared to more than 100 litres per day in the rainy season.

In Madagascar, it seems that milk collection was badly affected by the COVID-19 crisis. Traffic restriction measures subsequently reduced this flow. Many collectors complained about the long waiting time at roadside checkpoints, sometimes up to two hours, which of course resulted in milk losses (Midi Madagasikari, 31 March, 2020). In the same paper, it was reported that: "At least $50 \%$ of milk production is thrown away every day in highly productive areas such as Analamanga, Itasy and Vakinankaratra, because most of the collectors or processors no longer collect the product. Some still do, but after two days and in reduced quantities". Some even stopped collecting and processing milk for several weeks. Some dairies totally stopped buying and processing milk for 2 to 3 weeks. In the same region, many operators declared: "We do not have enough time to sell our stocks because retail points have to close before noon. This is a big loss, as it represents $75 \%$ of our production collected during the day". For Spring (another small dairy), milk collection dropped from 600 to 150 litres per day. Socolait, during the first few weeks of the health crisis, faced a large influx of milk because it benefited from other milk collectors that could no longer sell their milk to their usual processors (mainly small artisanal processors). However, Socolait was impacted negatively by the low demand in the following weeks and had to reduce milk collection.

\subsection{Imports of dairy products}

The share of imported dairy products is particularly high in West Africa (FAOSTAT data 2017; Chatellier, 2020): around $45 \%$ for Senegal (in milk equivalent), $25 \%$ for Burkina Faso, against only $12 \%$ for Madagascar and $6 \%$ for Kenya (based on the figures displayed in Tab. 1).

In Kenya, with curtailed movements from neighbouring countries and increased red tape in freight transportation, the country witnessed a decline in the flow of imported milk, particularly from Uganda. This benefited Kenyan producers through price stabilisation since the only supply of raw milk in the country at this time was from local farmers.

In Senegal, imports of milk powder did not stop. However, some delivery delays occurred owing to upstream disruptions in shipping logistics. For Senegalese dairy processors, maintaining imports of powdered milk was also decisive in safeguarding activity.

In Madagascar and Burkina Faso, we found no data indicating an increase or decrease in imports of milk powder and various dairy products since the start of the COVID-19 crisis.

Changes are most likely to occur in the medium to long term period of the crisis. In the short term, as local production seems to be more deeply impacted by the COVID-19 crisis than dairy imports in Western Africa and Madagascar, dairy imports could increase. Furthermore, in order to preserve its own currently oversupplied dairy sector (situation unrelated to the COVID-19 crisis), the EU is encouraging storage of milk powder, cheese and butter. Substantial volumes of cheap milk powder are therefore likely to be released on the world market in the coming months.

\subsection{Disruption of working arrangements in dairy processing units}

In Kenya, processors had to take precautionary measures in line with government guidelines, including employing more staff and increasing the number of work shifts in order to have fewer workers during each shift. This was brought about not only by physical distancing requirements, but also by the increase in the supply of milk to processing plants and in deliveries to consumer markets. However, according to the Daily Nation Newspaper (2 June, 2020), "all the dairy processors have been affected as the purchasing power of their customers has gone down due to many job cuts".

In Senegal, Laiterie du Berger had to look after its 400 or so employees. In consultation with its occupational health and safety committee, the company implemented official recommendations such as mask wearing, hand washing, social distancing between employees, working from home and bans on physical greetings. The company also decided to postpone recruitment, training, commercial events and marketing campaigns in order to restrict staff movements between the Dakar and Richard-Toll sites. In addition, the company decided to freeze investment projects, allocate additional funds to the fight against the pandemic, provide mobile washbasins and hand sanitizer dispensing points, and extend the use of masks for employees and communities near the processing plant. It has also recruited two doctors for the initial diagnosis of employees with symptoms or who feel exposed to the virus. All these measures affected the company's operations and impeded planning for more than a month.

In Burkina Faso, small dairy processing units have been operating at a slower pace since the emergence of COVID-19, as reported by the manageress of Bonnet Vert who is also Chairwoman of the dairy processors cooperative in BoboDioulasso. According to her estimate, dairies reduced their operations by $25 \%$. Dairies using imported milk powder were 
also affected, because processing activities could no longer be carried out after curfew hours (from $7 \mathrm{pm}$ to $5 \mathrm{am}$ ).

In Madagascar, the main consequence of the crisis for the dairy sector was the closure of artisanal cheese dairies, which accounted for $70 \%$ of processed milk. In most cases, employees were not paid, thereby exacerbating the social and economic crisis. The sudden temporary closure of these small businesses was partly linked to the difficulty in transporting processed products to consumers due to the traffic ban on public transporters, but also to the drop in demand stemming from the compulsory closure of shops in the afternoon, combined with the general fall in the standard of living as the crisis affected the country's economy as a whole. However, the influx of milk on the market led to an increase in milk quality reaching the gates of large dairy processors such as Socolait. Socolait was confronted with the challenge of quality control during the first weeks of the crisis, following a large influx of milk from producers unable to sell their milk through their usual collectors, and ignorant of the industrial quality standards.

\subsection{Disruptions in dairy market channels}

In Kenya, processors felt that the increase in milk production at farm level did not have a huge impact on their operations since, with children staying at home following school closures, their consumption of unprocessed milk increased significantly. Nevertheless, with the general public practicing self-isolation and social distancing, some buyers such as restaurants and local eateries that used to buy unprocessed milk, no longer did so. Therefore, this excess share of milk most likely ended up being sold directly to rural households. It was noted that consumer prices of milk went up by $7 \%$ in September 2020 (Andae, 2020) as production started declining due to drought. However, there were no promotion campaigns to increase milk consumption or prices since demand was already quite high.

In Senegal, shops had to close during curfew from $8 \mathrm{pm}$ to $6 \mathrm{am}$ in April, and then from $9 \mathrm{pm}$ to $5 \mathrm{am}$ in May during Ramadan. In addition, shops suffered from lack of consumer confidence since many traders were affected by COVID-19, especially in Dakar. This undoubtedly benefited supermarkets. They quickly complied with COVID-19 containment measures in order to reassure customers. However, the rise of supermarkets in the food retail sector had begun a few years ago, far before the onset of the pandemic.

In Burkina Faso, the manager of Labanko, a small dairy processor belonging to Plateforme Lait de Banfora, considered at the beginning of the health crisis that: "It is the distribution of processed products to customers that is most affected by the COVID-19 situation. Labanko normally markets its products over a large part of the country (from Bobo-Dioulasso to Ouagadougou) as well as in Korogho, in Ivory Coast. This is essentially carried out through public passenger transport companies. Since public transport has stopped, it has become impossible for Labanko to deliver its products to customers through this channel." In the Bobo-Dioulasso area, dairy processors complained about increasing losses of dairy products due to poor storage by distributors. Forced to close their shops earlier and accustomed to turning off their refrigerators overnight, distributors often found spoiled dairy products in the morning, which they returned to processors.

In Madagascar, the compulsory afternoon closing of retail stores and local markets considerably slowed down the sale of dairy products. As a result, sales dropped. But most importantly, the traffic ban affected transport to Antananarivo, a city that accounts for half of domestic consumption.

\subsection{Changes in consumer preferences}

In Kenya, demand for long life dairy products increased. Dairy product outlets such as supermarkets bought large quantities of long-life products and especially ultra-high temperature processed milk. This induced demand shock may be due to the fact that, with uncertainties in the dairy market, buyers and consumers sought to minimise spoilage. In particular, there was buying and hoarding of milk products by most retailers, though prices had not changed as shortages had not yet been experienced. Similarly, there was an increased demand for value-added products such as yoghurt and fermented milk because consumers wanted products they would store for longer periods without having frequent visits to supermarkets. This greater demand was a blessing for processors as value-added products also generate higher profits than fresh milk.

In Senegal, Laiterie du Berger and Kirène had anticipated an increase in demand for dairy products due to the month of Ramadan and the hot season. Overall, supermarkets and shops had built up large stocks of dry milk powder and long-life milk. Despite rumours of shortages, no shortage in milk supply was reported in Senegal.

In Burkina Faso, at the beginning of the crisis, the manager of Plateforme Lait de Banfora reported a drop in purchases from the local Banfora market. He attributed it to the curfew enforced from $7 \mathrm{pm}$ to $5 \mathrm{am}$ as well as to the decline in consumer buying power as a result of the general economic downturn in the country.

In Madagascar, demand for fresh dairy products (fresh milk and yoghurt) fell rapidly with the loss of purchasing power caused by the partial lockdown restrictions on the capital and main cities' major businesses, which also had an impact on informal sectors. However, consumers turned to long-life products such as powder and condensed milk.

\section{Crosscutting analysis and conclusion}

Fresh milk, like market garden products, is a highly perishable product. The milk supply chain is therefore very sensitive to any form of disturbance relating to the circulation of fresh milk and dairy products, the operation of processing units, the preservation of products in larger or smaller shops, as well as to all neglect of quality at all levels of the chain.

This paper shows that the impact of the COVID-19 outbreak on the four countries' economies and subsequent measures taken by governments to curb high levels of contamination among the public, had mixed effects on dairy supply chains.

At farm level: The consequences of COVID-19 measures were more pronounced when the health crisis coincided with the peak of the milk production season, and when governments 
did not take steps to support milk production, which was the case in three of the four countries studied. In Kenya, however, the government took measures to support the farm-gate price of milk, which helped curb the effects of containment policies at farm level. In Senegal and Burkina Faso, the dry season, during which milk production is generally low, somewhat concealed the impact of lockdown on dairy production and sales. In Madagascar, the COVID-19 outbreak occurred when milk production was at its peak. As a result, there was a sharp drop in the urban milk demand and in the farm-gate price of milk. Dairy farmers were hard hit by the containment measures taken to curb the outbreak. Part of the production could not be sold and was partly consumed by the producers or discarded.

At milk collection system level: The effects of traffic restrictions were quickly felt by small informal collectors who could not obtain traffic permits. Within the larger and more formal collection networks acknowledged by the authorities, collectors were granted the necessary licences to continue trading and to allow dairy products to move freely. In the large and well-established Kenyan and Senegalese milk collection networks, supply of milk from dairy farms to dairy processors was maintained during the health crisis. Some large dairy processors even benefited from an influx of milk, at least at the beginning of the crisis, as a result of the difficulties encountered in transporting milk through informal channels. In the small and relatively informal milk collection networks common in Burkina Faso and Madagascar, milk collection was quickly and severely affected by COVID-19 containment measures such as traffic bans. In these cases, health measures seriously disrupted the supply of milk from farms to processing units.

With regard to milk powder imports: No significant problem was reported in the import channels during the COVID-19 outbreak, especially in countries highly dependent on imports to supply their demand for milk such as Senegal and Burkina Faso. In African countries highly dependent on imports for their consumption of milk products, the authorities took measures ensuring that imports of these products would not be heavily affected. Import deadlines for milk powder were extended, but deliveries were not interrupted as all these countries have a stock of powdered milk at wholesalers' level corresponding to several months of consumption

At dairy processor level: The COVID-19 crisis and containment measures to curb the pandemic disrupted working arrangements and somewhat increased processing costs. Dairy processors faced many challenges to keep operating during the state of emergency, with constraints on traffic, employee protection and safety, etc. The impact of the COVID-19 crisis seems to have been greater on small milk processing units, due to temporary interruptions of milk supply resulting from traffic constraints for small informal collectors and difficulties in shipping dairy products by public transport.

With respect to dairy product distribution channels: The shock from COVID-19 was more pronounced among small retailers. Bans on public transport, routinely used to supply small dairy retailers, severely affected their business. Many small retailers reduced their purchases of artisanal dairy products. Losses of dairy products tended to increase with long curfews combined with poor storage conditions. Consumers also became wary of artisanal products and worried about health risks. This led to a sharp reduction in the number of processors' outlets, in particular retail stores and local markets. Supermarkets, on the other hand, were able to increase their market share during the pandemic thanks to their reliance on industrial channels.

At consumer level: Dairy consumption tended to decrease due to declining purchasing power. Consumers reduced their purchases of artisanal products. However, there was no collapse in consumption. In some situations, an increase in consumption occurred (in confined rather well-off urban families, in households of producers unable to sell their milk, during the month of Ramadan, etc.). During the first few months of the COVID-19 outbreak, a drop in milk consumption was reported by processors in Burkina Faso and Madagascar. In Kenya and Senegal however, dairy consumption does not seem to have been overly affected by the health crisis. In those two countries, consumption shifted towards long-life dairy products. In Senegal and Burkina Faso, dairy consumption increased despite the health crisis because this crisis occurred during the hot dry season and during the month of Ramadan.

Overall: Dairy supply chains appear to have suffered differently in each of the four countries, largely due to differences in the development of the local dairy industry. In most of our case studies, formal dairy supply chains (based on large and medium-sized milk processing companies) were more resilient than informal channels (based on small artisanal milk processors). Small and informal dairy supply chains were badly affected by the consequences of the health crisis. Large and more formal dairy processors were able to buy more milk from farmers in order to make up for the collapse of small processors and collectors. In most cases, dairy industries and supermarkets appeared to have played a major role during this period, thanks to their ability to reorganise their working procedures.

In Kenya, where the dairy industry boasts of a multitude of farm families, with a processing industry established for decades and a per capita consumption of dairy products three to four times higher than in the other countries under study, the government quickly took steps to support the dairy sector to preserve jobs and consumer supplies. These measures seem to have had the desired effects. In the other countries covered by the study, the dairy sector, whose contribution to the domestic economy is less significant, did not benefit from such support measures to the same extent. When such a crisis occurs, emergency support programs are needed, in addition to development programs that have already been well documented by many authors (Van der Lee et al., 2014), to revive local milk supply chains, in particular public support programs consistent with private strategies in order to strengthen connections and equity amongst value chain players. At the end of this study, we propose two types of recommendations to strengthen the resiliency of dairy supply chains:

First, for the "Large dairy supply chains", who have better withstood the first wave of the COVID-19 crisis, the measures which have worked and which could be strengthened are as follows: (1) supporting the milk price at farm gate; (2) providing authorizations for the circulation of dairy products, with appropriate controls; (3) maintaining product quality control all along the dairy supply chain to reassure consumers.

For the "Small dairy supply chains", which have been the most affected by the COVID-19 crisis, but which represent 
many small jobs, lower production costs under normal circumstances and consequently cheaper dairy products for consumers, their professionalization seems to be a priority in order to prevent their disappearance in case of recurrence of such crises in the future. The following axes could be proposed to support their professionalization: (1) the establishment of cross-cutting organizations integrating the different links of dairy supply chains (processors, producers, collectors, traders); (2) the recognition of a professional status for collectors and small dairy processors to enable them to obtain traffic authorizations in the event of similar crises; (3) the implementation of milk quality control at key points in the supply chain (at the entry docks of collection centres and dairies); (4) support through tax incentive mechanisms for small dairy processors and milk collection centres as for other sectors of the economy supported during this crisis.

\section{References}

Andae G. 2020. Kenya: Milk Prices Go Up Amid Supply Fall. Daily Nation. [30 September 2020]. https://allafrica.com/stories/ 202009300236.html.

Chatellier V. 2020. La dépendance de l'Afrique de l'Ouest aux importations de produits laitiers. INRAE Productions Animales 33: 125-140. DOI: 10.20870/productions-animales.2020.33.2.4027.

Corniaux C, Duteurtre G, Broutin C. 2014. Filières laitières et développement de l'élevage en Afrique de l'Ouest. L'essor des mini-laiteries. Paris (France) : Karthala, Coll. Homme et sociétés, $252 \mathrm{p}$.

Corniaux C, Duteurtre G. 2018. Étude relative à la formulation d'un programme régional de promotion des chaînes de valeur lait local au sein de la CEDEAO, de la Mauritanie et du Tchad. Rapport final. Étude réalisée par le CIRAD pour le compte du Hub Rural, Dakar, Sénégal, 105 p. + annexes.

Daily Nation Newspaper of June 2020. Dairy sector braves COVID19 disruption. Nairobi, Kenya. https:/www.nation.co.ke/kenya/ business/dairy-sector-braves-covid-19-disruption-354334.

Daily Nation Newspaper of April 2020. Dairy Brookside Dairy increases producer milk prices. https:/www.nation.co.ke/business/ Brookside-Dairy-increases-producer-milk-prices-/996-5509066k2gt4kz/index.html.
Droy I, Rasolofo P. 2018. Crise du lait et trajectoires de résilience des petits producteurs à Madagascar. Revue internationale des études $d u$ développement 3(235): 91-115. DOI: 10.3917/ried.235.0091.

FAO. 2020. FAOSTAT data on production, trade and consumption. http://www.fao.org/faostat/en/.

GRET. 2019. Étude filière lait dans les Bassins Laitiers de Ouagadougou et de Bobo-Dioulasso au Burkina Faso. GRET, Rapport définitif, $64 \mathrm{p}$.

Kiambia S, Orungo Ononoa J, Kang'ethea E, Abogea GO, Murungib MK, Muindeb P, et al. 2020. Investigation of the governance structure of the Nairobi dairy value chain and its influence on food safety. Preventive Veterinary Medicine 179: 105009. DOI: 10.1016/j.prevetmed.2020.105009.

Makoni N, Mwai R, Redda T, Van der Zijpp A, Van der Lee J. 2013. White Gold; Opportunities for Dairy Sector Development Collaboration in East Africa. Wageningen: Centre for Development Innovation, Wageningen UR. CDI Report CDI-14-006, 203 p.

Madagaskari M. 2020. Filière Or blanc: «Au moins 50\% de la production laitière est jetée chaque jour» dénonce Haingotiana Razafindrainibe, PCA de MDB. http://www.midi-madagasikara. $\mathrm{mg} /$ economie/2020/03/31/filiere-or-blanc-au-moins-50-de-la-pro duction-laitiere-est-jetee-chaque-jour-denonce-haingotiana-razafin drainibe-pca-de-mdb/.

Penot E, Duba G, Salgado P, Dugué P. 2016. Capacités d'adaptation des exploitations laitières des hautes terres de la province du Vakinankaratra à Madagascar : impacts de la crise de 2009. Revue d'Elevage et de Médecine Vétérinaire des Pays Tropicaux 69(1): 19-31. DOI: 10.19182/remvt.31168.

Richard D, Alary V, Corniaux C, Duteurtre G, Lhoste P, (Coord.). 2019. Dynamique des élevages pastoraux et agropastoraux en Afrique intertropicale. Versailles (France): Quae, 268 p. DOI: 10.35690/978-2-7592-2895-9.

Seck M, Marshall K, Fadiga ML. 2016. Cadre de politique pour le développement de la filière laitière au Sénégal. ILRI Project Report. Nairobi, Kenya: Institut International de Recherche sur l'Elevage.

Van der Lee J, Zijlstra J, Wouters AP, Van Vugt SM. 2014. Milking to Potential: Strategic Framework for Dairy Sector Development in Emerging Economies. Discussion paper. Wageningen UR, Wageningen: Centre for Development Innovation and Livestock Research, $30 \mathrm{p}$.

WHO. 2020. COVID-19 Outbreak situation reports $\mathrm{n}^{\mathrm{o}} 15$ [10 June 2020], $\mathrm{n}^{\mathrm{o}} 28$ [9 September 2020] and $\mathrm{n}^{\circ} 32$ [07 October 2020]. https://www.afro.who.int/health-topics/coronavirus-covid-19.

Cite this article as: Vall E, Mburu J, Ndambi A, Sall C, Camara AD, Sow A, Ba K, Corniaux C, Diaw A, Seck D, Vigne M, Audouin S, Rakotomalala LJE, Rakotonoely LN, Ferreira FD, Véromalalanirina E, Rajaonera M, Ouédraogo S, Sodré E, Tall I, Ilboudo MD, Duteurtre G. 2021. Early effects of the COVID-19 outbreak on the African dairy industry: Cases of Burkina Faso, Kenya, Madagascar, and Senegal. Cah. Agric. 30: 14. 